\title{
Effects of 2-methoxyestradiol on apoptosis and HIF-1 $\alpha$ and HIF-2 $\alpha$ expression in lung cancer cells under normoxia and hypoxia
}

\author{
ARNOLDO AQUINO-GÁLVEZ ${ }^{1 *}$, GEORGINA GONZÁLEZ-ÁVILA ${ }^{1 *}$, JAVIER DELGADO-TELLO ${ }^{1}$, \\ MANUEL CASTILLEJOS-LÓPEZ ${ }^{1}$, CRISELDA MENDOZA-MILLA ${ }^{1}$, JOAQUÍN ZÚÑIGA ${ }^{1}$, \\ MARCO CHECA $^{1}$, HÉCTOR AQUILES MALDONADO-MARTÍNEZ ${ }^{2}$, AXEL TRINIDAD-LÓPEZ ${ }^{1}$, \\ JOSÉ CISNEROS ${ }^{1}$, LUZ MARÍA TORRES-ESPÍNDOLA ${ }^{3}$, CLAUDIA HERNÁNDEZ-JIMÉNEZ ${ }^{1}$, \\ BETTINA SOMMER ${ }^{1}$, CARLOS CABELLO-GUTIÉRREZ ${ }^{1}$ and LUIS H. GUTIÉRREZ-GONZÁLEZ ${ }^{1 *}$ \\ ${ }^{1}$ Instituto Nacional de Enfermedades Respiratorias 'Ismael Cosío Villegas'; ${ }^{2}$ Instituto Nacional de Cancerología; \\ ${ }^{3}$ Instituto Nacional de Pediatría, Mexico City, DF, Mexico
}

Received June 10, 2015; Accepted August 20, 2015

DOI: $10.3892 /$ or.2015.4399

\begin{abstract}
Hypoxic tumor cells are known to be more resistant to conventional chemotherapy and radiation than normoxic cells. However, the effects of 2-methoxyestradiol (2-ME), an anti-angiogenic, antiproliferative and pro-apoptotic drug, on hypoxic lung cancer cells are unknown. The aim of the present study was to compare the effects of 2-ME on cell growth, apoptosis, hypoxia-inducible factor $1 \alpha$ (HIF-1 $\alpha$ ) and HIF-2 $\alpha$ gene and protein expression in A549 cells under normoxic and hypoxic conditions. To establish the optimal 2-ME concentration with which to carry out the apoptosis assay and to examine mRNA and protein expression of HIFs, cell growth analysis was carried out through N-hexa-methylpararosaniline staining assays in A549 cell cultures treated with one of five different 2-ME concentrations at different times under normoxic or hypoxic growth conditions. The 2-ME concentration of $10 \mathrm{mM}$ at $72 \mathrm{~h}$ was selected to perform all further experiments. Apoptotic cells were analyzed by flow cytometry. Western blotting was used to determine HIF- $1 \alpha$ and HIF- $2 \alpha$ protein expression in total cell extracts. Cellular localization of HIF-1 $\alpha$ and HIF- $2 \alpha$ was assessed by immunocytochemistry. HIF-1 $\alpha$ and HIF- $2 \alpha$ gene expression was determined by real-time PCR. A significant increase in the percentage of apoptosis was observed when cells were treated with 2-ME under a normoxic but not under hypoxic conditions $(\mathrm{p}=0.006)$. HIF-1 $\alpha$ and
\end{abstract}

Correspondence to: Dr Georgina González-Ávila or Dr Luis H. Gutiérrez-González, Instituto Nacional de Enfermedades Respiratorias 'Ismael Cosío Villegas', Calzada de Tlalpan 4502, Sección XVI, Mexico City, DF 14080, Mexico

E-mail: ggonzalez@yahoo.com

E-mail: 1hgut@iner.gob.mx

*Contributed equally

Key words: apoptosis, cancer, HIF-1 $\alpha$, HIF-2 $\alpha, 2$-methoxyestradiol, hypoxia
HIF-2 $\alpha$ protein expression levels were significantly decreased in cells cultured under hypoxic conditions and treated with 2 -ME $(\mathrm{p}<0.001)$. Furthermore, 2-ME decreased the HIF-1 $\alpha$ and HIF- $2 \alpha$ nuclear staining in cells cultured under hypoxia. The HIF- $1 \alpha$ and HIF- $2 \alpha$ mRNA levels were significantly lower when cells were exposed to 2-ME under normoxia and hypoxia. Our results suggest that 2-ME could have beneficial results when used with conventional chemotherapy in an attempt to lower the invasive and metastatic processes during cancer development due to its effects on the gene expression and protein synthesis of HIFs.

\section{Introduction}

Hypoxia is an event that allows neoplastic cells from the primary tumor to become metastatic cells $(1,2)$. It also influences the formation of new vessels by upregulating the expression of VEGF (3). It has been established that cellular response to hypoxia is mediated by hypoxia-inducible factors (HIFs), which are transcriptional factors that promote the expression of genes involved in cell survival under hypoxic conditions. They also participate directly in other processes of tumoral development such as neoplastic glucose/energy metabolism, cellular growth and apoptosis $(4,5)$. HIFs are heterodimers consisting of either HIF- $1 \alpha$ or HIF- $2 \alpha$ bound to the HIF-1 $\beta$ subunit. In normoxic conditions, the $\alpha$ subunit is constitutively expressed but rapidly degraded. In a low-oxygen environment, the $\alpha$ subunit is stabilized and translocated to the nucleus $(6,7)$. Therefore, both HIF- $\alpha$ subunits are regulated by $\mathrm{O}_{2}$ availability, while HIF-1 $\beta$ is constitutively expressed.

2-Methoxyestradiol (2-ME) is an anti-angiogenic, antiproliferative and pro-apoptotic agent that suppresses HIF-1 $\alpha$ protein levels and its transcriptional activity $(8,9)$. Its effect correlates with a decrease in tubulin polymerization (10) and it also disrupts normal microtubule function and stability (11). 2-ME binds directly to the colchicine binding site and does not interact with estrogen receptors, lowering therefore its probable side-effects (12). 2-ME may have potential clinical benefit in 
the treatment of cancer since it inhibits the proliferation of many human cancer cell lines in vitro $(13,14)$. There is evidence that HIF-1 $\alpha$ mediates tumoral cell survival and apoptosis resistance under hypoxic and normoxic conditions $(15,16-18)$. Furthermore, the pharmacological inhibition of HIF-1 $\alpha$, and particularly HIF-regulated genes that are important for cancer cell survival, may be more advantageous than HIF-gene inactivation therapeutic approaches (19).

Hypoxic tumor cells are known to be more resistant to current treatment modalities and to radiation than normoxic cells (20). Hypoxia can also confer resistance against chemotherapy-induced apoptosis in numerous solid tumors such as breast and non-small cell lung cancer and pancreatic ductal adenocarcinoma (21-23). Therefore, and considering hypoxia as an important factor leading cancer cells to enhanced resistance to cytotoxic drugs, we studied the effects of 2-ME on cell growth, apoptosis, and HIF- $1 \alpha$ and HIF- $2 \alpha$ gene and protein expression in human lung adenocarcinoma A549 cells grown under normoxic and hypoxic conditions.

\section{Materials and methods}

The protocol was approved by the local Ethics and Research Committees.

Cell culture. The A549 human lung adenocarcinoma cell line was obtained from the American Type Culture Collection (ATTC; Rockville, MD, USA). Cells were cultured in Dulbecco's modified Eagle's medium (DMEM) containing $10 \%$ fetal bovine serum (FBS) and supplemented with non-essential amino acids, $50 \mathrm{U} / \mathrm{ml}$ penicillin and $50 \mu \mathrm{g} / \mathrm{ml}$ streptomycin at $37^{\circ} \mathrm{C}$ in a humidified atmosphere with $5 \%$ $\mathrm{CO}_{2} / 95 \%$ air.

Cell growth assay. After cells reached $80 \%$ confluence, $2 \times 10^{4}$ cells/well were cultured into 48 -well plates for $24 \mathrm{~h}$. A stock solution of $33 \mathrm{mM}$ 2-ME (Sigma-Aldrich, St. Louis, MO, USA) was prepared in dimethyl sulfoxide (DMSO). Final 2-ME concentrations were prepared by diluting the stock solution with DMEM. Medium was replaced with fresh medium with $10 \%$ FBS and with the corresponding 2-ME concentrations (0.001, 0.1, 0.1, 1 and $10 \mu \mathrm{M}$ final concentrations). A549 cells with $10 \%$ FBS medium (non-stimulated cells) were used as growth control. Cells were also cultured with $10 \%$ FBS plus $0.03 \%$ DMSO (vehicle-control group for all experiments). Cells were cultured for $12,24,48,72$ and $96 \mathrm{~h}$ in normoxia $\left(5 \% \mathrm{CO}_{2}\right.$ and $95 \%$ air) and hypoxia (1\% oxygen and $\left.5 \% \mathrm{CO}_{2}\right)$ conditions, at $37^{\circ} \mathrm{C}$ in a humidified incubator. The culture medium, with and without 2-ME, was not changed during the assay.

Cells were placed into a chamber MIC-101 (BillupsRothenberg, Del Mar, CA, USA) to expose them to hypoxic conditions. Briefly, a mixture of $95 \%$ nitrogen and $5 \% \mathrm{CO}_{2}$ gas that displaces the oxygen into the chamber was injected. The oxygen concentration was measured by an oxygen sensor (Vascular Technology, Nahua, NH, USA) and maintained at $1 \%$. At the end of the incubation period, the media were discarded and the cells were washed with phosphate-buffered solution. Five hundred microliters of $1 \%$ glutaraldehyde solution were added to each well and incubated for $20 \mathrm{~min}$ at room temperature; subsequently the glutaraldehyde solution was discarded and $0.1 \%$ crystal violet ( $\mathrm{N}$-hexamethylpararosaniline) (Sigma-Aldrich) solution was added to each well and incubated under constant stirring for $15 \mathrm{~min}$ at room temperature. Crystal violet was washed exhaustively, allowed to dry and afterwards $400 \mu \mathrm{l}$ of $10 \%$ acetic acid solution were added to each well. The sample absorbance was measured at $590 \mathrm{~nm}$ in 96-well microtiter plates with an ELISA reader (Molecular Devices, Sunnyvale, CA, USA). All experiments were carried out in triplicate. Cell growth was expressed as the relative increase in light absorbance at $590 \mathrm{~nm}$ with respect to the value at $0 \mathrm{~h}$.

Apoptosis assay. A549 cells were cultured in 6-well plates ( $3 \times 10^{5}$ cells/well) under normoxic or hypoxic conditions for $72 \mathrm{~h}$. Three different media were used: DMEM (control), DMEM with DMSO (without 2-ME) and DMEM with $10 \mu \mathrm{M}$ 2-ME. Apoptosis was examined by flow cytometry using the Annexin V (Becton-Dickinson Biosciences, Franklin Lakes, NJ, USA) staining kit. Briefly, $1 \times 10^{6}$ cells in $100 \mu$ l Annexin buffer were stained with propidium iodide and FITC-Annexin V staining solutions. Cells were incubated at room temperature in the dark for $15 \mathrm{~min}$, and the data were subsequently acquired through a FACSAria flow cytometer (Becton-Dickinson Biosciences). Data were analyzed using the FlowJo X.0.7 software (Stanford University, Stanford, CA, USA). Results are expressed as percentage; $100 \%=5,000$ cells.

Western blotting. Cells were plated into 6-well cell culture plates and were grown until they reached $60 \%$ confluence. Cells were then exposed to hypoxic conditions and lysed with $0.1 \%$ Triton (Sigma-Aldrich) in PBS without calcium to obtain total cell extracts. Protein quantification was performed by the bicinchoninic acid protein assay (BCA protein assay kit; Pierce Biotechnology, Rockford, IL, USA). Western blotting was carried out using $30 \mu \mathrm{g}$ of cell extract proteins in $8 \%$ SDS-polyacrylamide gels (PAGE) under reducing conditions with 5\% 2-mercaptoethanol boiled for $10 \mathrm{~min}$. After electrophoresis, the proteins were transferred to PVDF membranes and blocked with $2.5 \%$ non-fat dry milk in $100 \mathrm{mM}$ Tris- $\mathrm{HCl}$ buffer, $\mathrm{pH} 7.5$ with $150 \mathrm{mM} \mathrm{NaCl}$ and $0.1 \%$ Tween-20 (TTBS buffer); they were then incubated for $90 \mathrm{~min}$ at room temperature with the corresponding antibody: 1:500 anti-HIF-1 $\alpha$ (mouse monoclonal antibody, NB100-479) or 1:500 anti-HIF-2 $\alpha$ (rabbit polyclonal antibody, NB100-122) (both from Novus Biologicals, Littleton, CO, USA). $\beta$-tubulin antibody (1:500) was used as a loading control (sc-53140; Santa Cruz Biotechnology, Santa Cruz, CA, USA). Unbound antibodies were washed with TTBS buffer and bands were detected using the Vectastain ${ }^{\circledR}$ ABC kit (Vector Laboratories, Burlingame, CA, USA). Western blotting bands were analyzed by densitometry scanning using the Kodak Digital Science ID Image analysis software (Eastman Kodak, Rochester, NY, USA). The results are expressed as densitometry units (DU).

Immunocytochemistry. Five hundred thousand cells were cultured in a Nunc Lab-Tek chamber slide system (Thermo Fisher Scientific, Carlsbad, CA, USA) and allowed to grow in normoxia or hypoxia with or without $10 \mu \mathrm{M} 2-\mathrm{ME}$ treatment for $72 \mathrm{~h}$. The cells were fixed with $1 \%$ glutaraldehyde (Sigma-Aldrich) and washed thrice with distilled water for 5 min. Antigen retrieval was performed with 1:10 citrate 
buffer (Sigma-Aldrich). The slides were heated during $5 \mathrm{~min}$ in a microwave and they were then allowed to cool for $20 \mathrm{~min}$. Endogenous peroxidase activity was quenched with $2 \% \mathrm{H}_{2} \mathrm{O}_{2}$ solution (Sigma-Aldrich). Antibody blockade and incubation were performed in a humid chamber with $100 \mu \mathrm{l}$ of blocking solution with serum, followed by the blockade of non-specific sites with $4 \%$ (wt/vol) non-fat dry milk in PBS at $4^{\circ} \mathrm{C}$ overnight. Cells were incubated with $100 \mu \mathrm{l}$ of the corresponding antibody for $90 \mathrm{~min}$ at room temperature: 1:100 anti-HIF-1 $\alpha$ (mouse monoclonal antibody, 1NB100-479) or 1:100 anti-HIF-2 $\alpha$ (rabbit polyclonal antibody, NB100-122; Novus Biologicals). In another set of experiments, cells were processed with a non-immune $\operatorname{IgG}$ instead of the primary antibody as a negative control. Visualization of antibody localization was achieved with a Vectastain ${ }^{\circledR}$ ABC detection kit. Between each step, the slides were thoroughly washed with distilled water. Finally, the slides were manually counterstained with Harris hematoxylin and mounted with non-aqueous medium. Images were captured with an Evos-FL Auto microscope (Thermo Fisher Scientific).

RT-PCR and quantitative real-time PCR of HIF-1 $\alpha$ and $H I F-2 \alpha$. Cells were incubated under normoxic or hypoxic conditions with or without $10 \mu \mathrm{M} 2-\mathrm{ME}$ for $72 \mathrm{~h}$. After incubation, total RNA and protein were extracted. RNA was extracted using TRIzol reagent (Invitrogen Life Technologies, Thermo Fisher Scientific) and reverse transcribed into cDNA (Advantage RT-for-PCR kit; Clontech, Palo Alto, CA, USA). One microgram of total RNA was reverse transcribed using $2 \mu \mathrm{g}$ of random primers and Moloney murine leukemia virus reverse transcriptase according to the manufacturer's protocol (Advantage RT-for-PCR kit). Real-time PCR was carried out on a One-Step system (Applied Biosystems, Thermo Fisher Scientific). The expression assay was carried out using predesigned TaqMan gene expression assay Hs00153153 for HIF-1 $\alpha$ labeled with FAM, Hs01026149_m1 for HIF-2 $\alpha$ labeled with FAM and normalized with Hs99999901_s1 for $18 \mathrm{~S}$ ribosomal RNA labeled with VIC (Applied Biosystems). The PCR duplex reactions were performed in a $20-\mu 1$ reaction volume containing $10 \mu \mathrm{l}$ of TaqMan Universal PCR Master Mix 2X, $0.5 \mu \mathrm{l}$ of TaqMan gene expression assay Hs99999901_s1 20X used as an endogenous control (18S rRNA), $1 \mu \mathrm{l}$ TaqMan gene expression assay of the target gene (Hs00153153 or Hs01026149_m1), 50 ng of cDNA (4 $\mu \mathrm{l})$ and $4 \mu \mathrm{l}$ of RNAse-free water.

Relative quantitation method was used to analyze the results of two independent experiments made in triplicate. For each experimental sample, a gene was considered as not expressed if amplification was not detected by threshold cycle $\mathrm{Ct}=40$. The results are expressed in arbitrary units of $\Delta \mathrm{Ct}$, where $\Delta \mathrm{Ct}=\mathrm{Ct}_{\text {target }}-\mathrm{Ct}_{18 \mathrm{~s}} \cdot \Delta \mathrm{Ct}$ values represent mRNA transcripts.

Statistical analysis. Cell growth was expressed as a percentage of their relative controls. The mean and standard deviation (SD) were obtained in triplicate. Differences between experimental assays in hypoxia, normoxia (0, 12, 24, 48, 72 and $96 \mathrm{~h})$ and apoptosis assays were analyzed using the Student's t-test. Statistical analysis was conducted using the statistical software SPSS version 20.0 (IBM SPSS). $\mathrm{p} \leq 0.05$ was considered to indicate a statistically significant result.

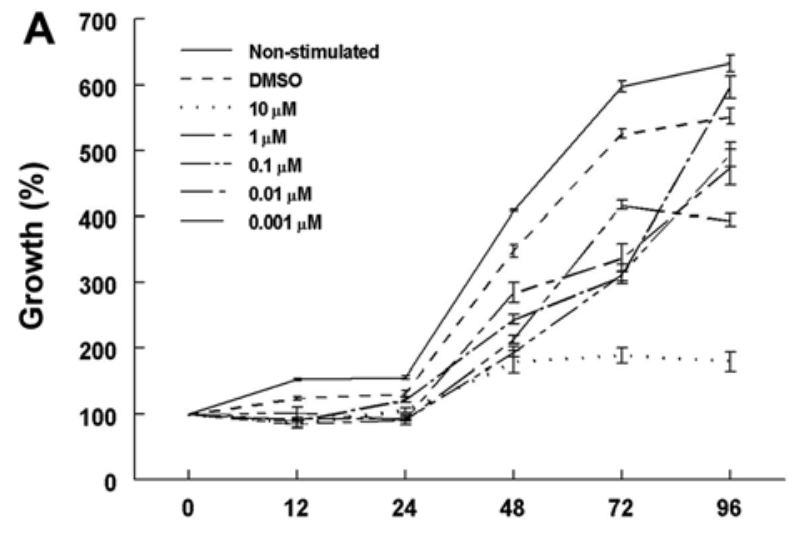

(h)

\section{B}

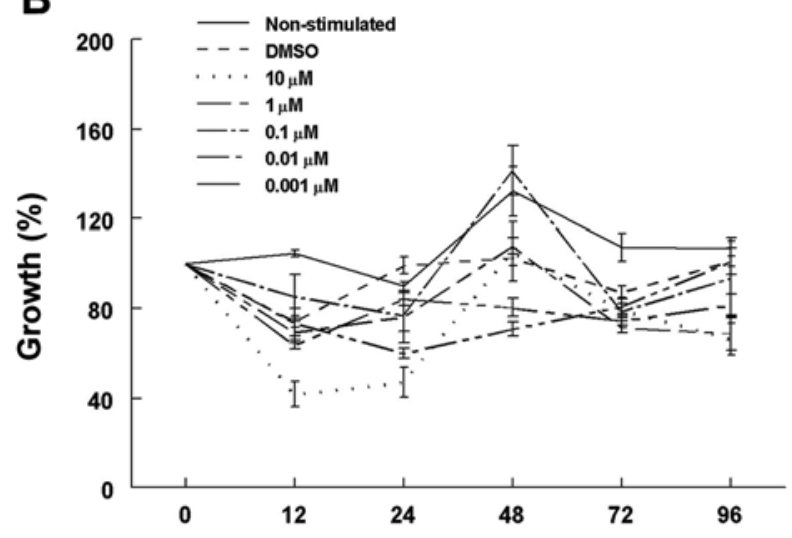

(h)

Figure 1. Dose- and time-dependent growth rate of 2-ME-treated A549 cells. (A) Normoxic conditions. A549 cells treated with different concentrations of 2-ME dissolved in DMSO or DMSO alone (control cells) were allowed to grow for different time lengths. Significant differences $(\mathrm{p}<0.0001)$ were observed from 48 to $96 \mathrm{~h}$ growth periods for the $10 \mu \mathrm{M}$ 2-ME-treated cells. (B) Hypoxic conditions. Cells treated with different concentrations of 2-ME or DMSO were cultured in $1 \% \mathrm{O}_{2}$ during different time periods and showed no differences among their growth rates. Cell growth was expressed as a percentage. Values for each data point represent mean \pm SD of triplicates.

\section{Results}

2-ME inhibits cell growth and induces apoptosis in A549 cells under normoxic but not hypoxic conditions. Cell growth rates in the 2-ME-stimulated cells were decreased in comparison to the rates in the DMSO-incubated control cells, mainly at 48 and $72 \mathrm{~h}$ under normoxic conditions (Fig. 1A). The lowest cell growth rate was observed using a $10 \mu \mathrm{M}$ concentration of 2-ME in comparison with the DMSO control cells: $179.4 \pm 16.6$ and $347.7 \pm 9.6 \%$, respectively $(\mathrm{p}<0.0001)$ at $48 \mathrm{~h} ; 189.0 \pm 11.6$ and $526.3 \pm 7.2 \%$, respectively $(\mathrm{p}<0.0001)$ at $72 \mathrm{~h}$, and $179.7 \pm 14.2$ and $552.9 \pm 12.1 \%$, respectively $(\mathrm{p}<0.0001)$ at $96 \mathrm{~h}$. In contrast, there were no significant differences among the growth rates between the control cells and those treated with $10 \mu \mathrm{M} 2-\mathrm{ME}$ at 72 and $48 \mathrm{~h}$ under hypoxic conditions (Fig. 1B). However, a significant decrease in the growth rate was found in the $10 \mu \mathrm{M}$ 2-ME-treated cells in comparison with the DMSO-treated cells $(66.2 \pm 7.2$ and $101.2 \pm 2.3 \%$, respectively; $p=0.04)$ at $96 \mathrm{~h}$. An exponential cell growth was observed in the DMSO medium without stimulation, as expected. 
A

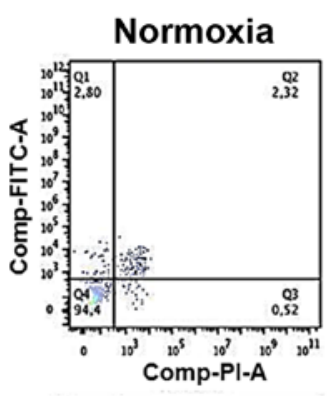

Control

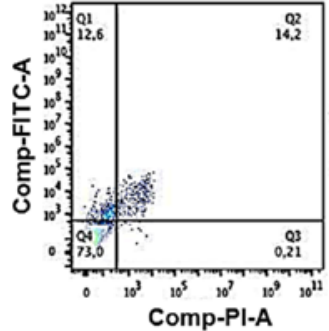

DMSO

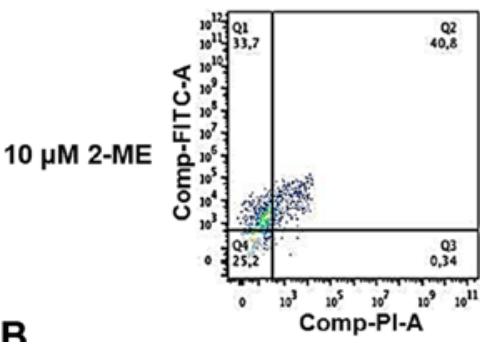

B

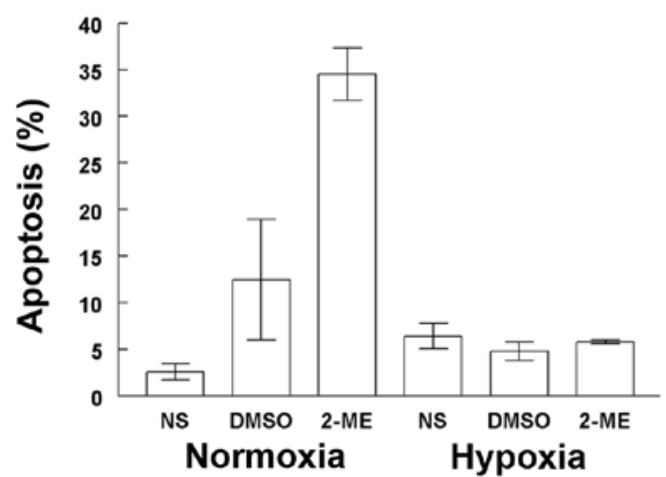

Figure 2. Effects of 2-ME on A549 cell apoptosis. (A) Flow cytometry of A549 cells grown for $72 \mathrm{~h}$ under normoxia (left three panels) or hypoxia (right three panels). The dot plots show the percentage of apoptosis (Q1) in the control cells without DMSO (top panels), control cells with DMSO (middle panels) and cells exposed to $10 \mu \mathrm{M} 2-\mathrm{ME}$ (bottom panels). (B) Apoptosis (\%). Bar graph showing apoptosis in the different groups studied. Significance was observed in the A549 cells exposed to $10 \mu \mathrm{M}$ 2-ME ( $\mathrm{p}=0.006)$ under normoxic condition when compared to the control group without treatment. A significant decrease was observed between cells under normoxic and hypoxic conditions $(\mathrm{p}=0.003)$ under $2-\mathrm{ME}$ treatment. Bars indicate the mean $\pm \mathrm{SD}$ of triplicate results.

2-ME at a concentration of $10 \mu \mathrm{M}$ was used for the apoptosis and HIF-1 $\alpha$ and HIF-2 $\alpha$ expression assays, due to the significance found for this concentration when cells were incubated under normoxic conditions at $72 \mathrm{~h}$. Longer incubation periods were not used since absence of nutrients could have biased the results. Apoptosis induced by $2-\mathrm{ME}$ in the A549 cells was differentially affected by the oxygenation conditions (Fig. 2A). The presence of $10 \mu \mathrm{M}$ 2-ME significantly increased the percentage of apoptosis $(34.5 \pm 2.8 \%)$ in comparison with the DMSO control cells $(12.5 \pm 6.5 \%)$

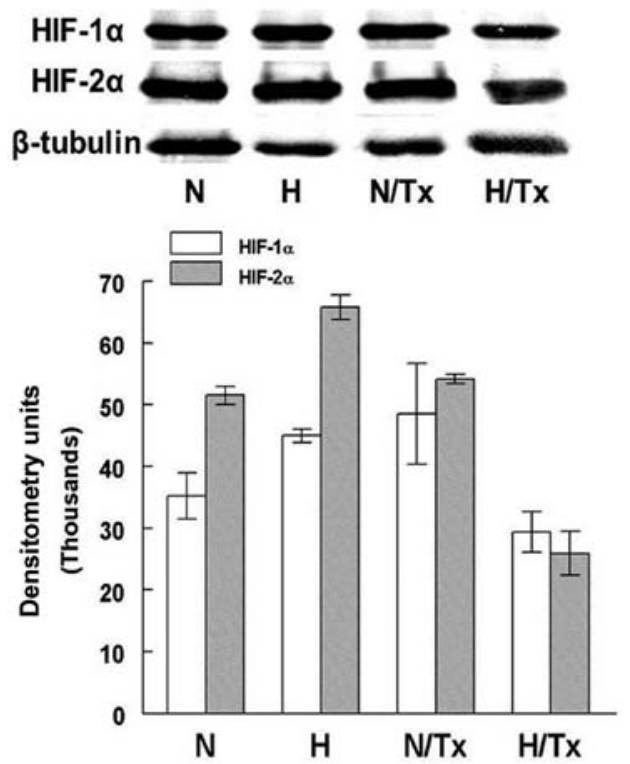

Figure 3. HIF-1 $\alpha$ and HIF-2 $\alpha$ immunoblot assay. Western blotting showed the presence of both HIF- $1 \alpha$ and HIF- $2 \alpha$ in all experimental conditions. The largest protein expression corresponds to HIF-2 $\alpha$ in hypoxic conditions $(\mathrm{p}=0.02)$ in comparison with HIF-1 $\alpha$. The synthesis of both proteins was significantly decreased when cells were exposed to $10 \mu \mathrm{M} 2-\mathrm{ME}$ in hypoxic conditions $(\mathrm{p} \leq 0.001)$. All experiments were carried out for $72 \mathrm{~h}$. Bars represent the mean \pm SD of triplicates. $\mathrm{N}$, normoxic; $\mathrm{H}$, hypoxic; N/Tx, cells cultured under normoxic condition treated with 2-ME; H/Tx, cell cultured under hypoxic conditions treated with 2-ME.

$(\mathrm{p}=0.006)$ and non-stimulated cells (NS) $\left(\mathrm{p}=4.8 \times 10^{-5}\right)$ in a normoxic condition. There were no significant differences among $10 \mu \mathrm{M}$ 2-ME-treated and control cells grown under hypoxic conditions. A significant increase in apoptosis was observed in cells treated with $10 \mu \mathrm{M} 2-\mathrm{ME}$ in a normoxic condition in comparison with cells under lower $\mathrm{O}_{2}$ concentration $(5.8 \pm 0.2 \%$; $=0.003)$ (Fig. 2B).

Western blotting for HIF-1 $\alpha$ and HIF-2 $\alpha$. Western blot densitometry analysis showed differences in the protein expression of HIF-1 $\alpha$ and HIF-2 $\alpha$ under hypoxic conditions (Fig. 3).

HIF-1 $\alpha$ was significantly increased in hypoxic cells $(44,998.1 \pm 1,079.3 \mathrm{DU})$ in comparison with cells cultured in normoxic conditions $(35,200.8 \pm 3,726.9 \mathrm{DU} ; \mathrm{p}=0.01)$. HIF- $1 \alpha$ protein expression was not modified when the cells were treated with 2-ME in a normoxic condition. In contrast, there was a decrease in HIF-1 $\alpha$ when cells were treated with 2-ME under hypoxic conditions $(29,390.1 \pm 3,542.9 \mathrm{DU} ; \mathrm{p}=0.001)$.

HIF- $2 \alpha$ protein levels were significantly increased in the cells cultured under hypoxia $(65,834.3 \pm 1,957.7 \mathrm{DU})$ in comparison with cells incubated under a normoxic condition $(51,537 \pm 1,451.3 \mathrm{DU}, \mathrm{p}=0.001)$. The synthesis of this protein was not significantly modified by the exposure to $2-\mathrm{ME}$ under a normoxic condition. In contrast, the HIF- $2 \alpha$ level was significantly decreased in cells treated with $10 \mu \mathrm{M} 2-\mathrm{ME}$ under hypoxic conditions $\left(25,921 \pm 3,5442.9 \mathrm{DU} ; \mathrm{p}=6.8 \times 10^{-5}\right)$.

Significant differences were also found when HIF-1 $\alpha$ and HIF- $2 \alpha$ levels of cells grown under normoxic $(p=0.02)$ and hypoxic conditions $\left(\mathrm{p}=8.6 \times 10^{-3}\right)$ were compared, but not among the same cell groups treated with 2-ME. 


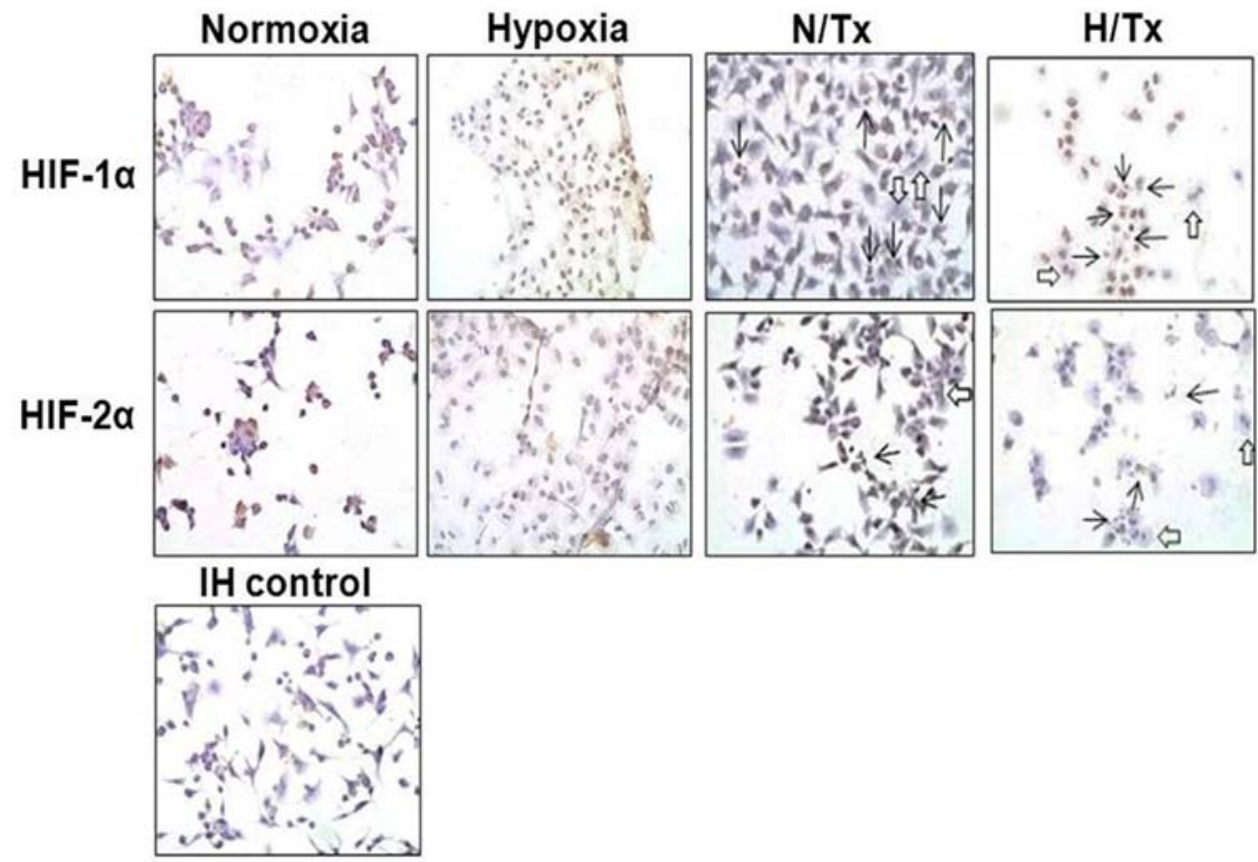

Figure 4. HIF-1 $\alpha$ and HIF-2 $\alpha$ immunocytochemistry in 2-ME-treated A549 cells. Cells were cultured under normoxia (first and third columns) or hypoxia (second and fourth columns) and with (third and fourth columns) or without (first and second columns) $10 \mu \mathrm{M}$ 2-ME. Both HIFs showed modest but similar reduction in the extent and intensity of expression in the cells treated with 2-ME. Open arrows indicate nuclear lobation; solid arrows indicate nuclear fragmentation. IH control (bottom panel), immunocytochemistry control cells without the primary antibody. Magnification, $\mathrm{x} 400$.

HIF-1 $\alpha$ and HIF-2 $\alpha$ immunocytochemistry in 2-ME-treated cells. HIF- $1 \alpha$ and HIF- $2 \alpha$ were detected in the normoxic-grown cell cytoplasm, particularly HIF-2 $\alpha$, using immunoperoxidase staining (Fig. 4). When cells were cultured under hypoxic conditions, HIF-1 $\alpha$ was observed with higher intensity in the cell nucleus; however, staining for HIF-2 $\alpha$ was low. Neither HIF-1 $\alpha$ nor HIF- $2 \alpha$ were noted in the cells treated with 2-ME under a normoxic condition. The incubation with 2-ME decreased the nuclear staining for HIF-1 $\alpha$ in cells under hypoxia, while no staining for HIF- $2 \alpha$ was observed under the same experimental conditions.

Apart from the effects of 2-ME on HIF-1 $\alpha$ and HIF-2 $\alpha$ protein expression in both experimental conditions, some morphological and physiological effects were also evident. Nuclear lobation (open arrows) and nuclear fragmentation (apoptosis, solid arrows) were present in cells treated with 2-ME under a normoxic condition; these phenomena were more frequent in cells exposed concomitantly to hypoxia and 2-ME.

HIF-1 $\alpha$ and HIF-2 $\alpha$ gene expression. The gene expression assay revealed that there were significant differences in HIF-1 $\alpha$ mRNA expression among normoxic $(5.9 \pm 0.9 \Delta \mathrm{Ct}$ values $)$ and hypoxic $(9.2 \pm 0.8 \Delta \mathrm{Ct}$ values; $\mathrm{p}=0.0004)$ cells (Fig. 5). A significant decrease in HIF-1 $\alpha$ mRNA expression was observed when cells were cultured with 2-ME under a normoxic $(0.63 \pm 0.3 \Delta$ Ct values; $\mathrm{p}=0.03)$ condition. HIF- $1 \alpha$ mRNA was untraceable in cells exposed to 2-ME under hypoxia.

There were no differences in HIF-2 $\alpha$ mRNA expression among cells cultured under normoxic and hypoxic conditions. When normoxic-grown cells were exposed to 2-ME, HIF-2 $\alpha$ gene expression was significantly decreased $(0.3 \pm 0.1 \Delta \mathrm{Ct}$ values) in comparison with the untreated cells $(3.9 \pm 0.4 \Delta \mathrm{Ct}$

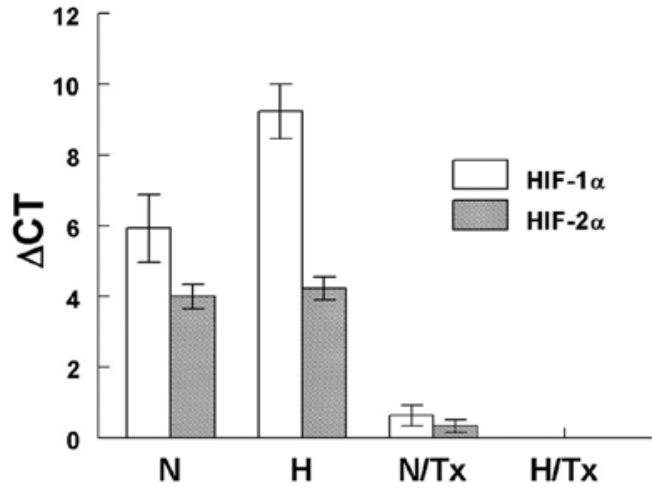

Figure 5. HIF-1 $\alpha$ and HIF-2 $\alpha$ mRNA expression. A significant increase $(\mathrm{p}=0.0004)$ was observed in HIF-1 $\alpha$ but not in HIF-2 $\alpha$ gene expression under hypoxic conditiono. The mRNA expression was significantly decreased ( $\leq \leq 0.03)$ when cells were treated with $10 \mu \mathrm{M} 2-\mathrm{ME}$ under normoxic and hypoxic conditions. Bars represent the mean \pm SD of triplicates. N, normoxic; $\mathrm{H}$, hypoxic; N/Tx, cells cultured under a normoxic condition treated with 2-ME; H/Tx, cell cultured under a hypoxic condition treated with 2-ME.

values; $\mathrm{p}=0.02$ ). Neither HIF-1 $\alpha$ nor HIF- $2 \alpha$ mRNA was detected in hypoxic cells exposed to 2-ME.

The mRNA expression of HIF-1 $\alpha$ was significantly higher than HIF- $2 \alpha$ gene expression under hypoxia $(\mathrm{p}=0.04)$; but no differences were noted when mRNA expression for HIF-1 $\alpha$ and HIF-2 $\alpha$ grown in normoxic conditions was compared.

\section{Discussion}

2-Methoxyestradiol (2-ME) is a natural metabolite of $17 \beta$-estradiol that exerts antiproliferative action in 
carcinoma cell lines and may play a possible antitumor and anti-angiogenesis role in vivo $(8,24-26)$. Furthermore, it has also been used in a number of preclinical and clinical studies for the treatment of solid tumors (27-29). Likewise, it is widely known that hypoxic microenvironments inside solid tumors are one of the major causes of drug resistance $(15,30,31)$, and that the extent of tumor hypoxia is an important prognostic factor for assessing tumor progression as well as resistance to therapy and overall patient survival (32-34). Under hypoxic conditions, some genes, such as the hypoxia-inducible factors (HIFs), are activated and their products favor tumor progression. In the present study, we analyzed whether 2-ME could inhibit the expression of HIF genes in lung carcinoma cells simultaneously exposed to this drug and hypoxia. The effect of different 2-ME concentrations on cell growth rates of human adenocarcinoma A549 cells grown under normoxia or hypoxia was analyzed first. Our results showed a dose-dependent inhibition of cell growth for 2-ME-treated normoxic cells. In contrast, a strong cell growth inhibition, probably due to the hypoxia rather than to 2-ME treatment, was observed. The effects of this compound on apoptosis were also examined, since there is evidence that HIF-1 $\alpha$ mediates tumoral cell survival and apoptotic resistance under hypoxic and normoxic conditions (15-18). We observed that, under a normoxic condition, 2-ME stimulated apoptosis, an effect probably due to $\mathrm{Bcl}-2$ and $\mathrm{Bcl}-\mathrm{xL}$ phosphorylation and the subsequent inhibition of the anti-apoptotic effects (35). Contrastingly, 2-ME had no effect on cells grown under hypoxia. Notably, this 2-ME lack of effect was concentration independent. This finding correlates with the observation that hypoxia by itself prevents several agents such as the ones used in chemotherapy from inducing apoptosis $(17,36,37)$. Likewise, the possibility that HIF-1 $\alpha$ could display either a pro-apoptotic or an anti-apoptotic role has been raised and it has been proposed that HIF-1 $\alpha$ acting one way or the other is probably related to the severity of the hypoxic conditions (36).

It has been determined that 2-ME inhibits the expression of HIF-1 $\alpha$ and HIF-2 $\alpha$ proteins and their nuclear translocation in hepatocellular carcinoma cells (31). Accordingly, we also found a significant decrease in HIF- $1 \alpha$ and HIF- $2 \alpha$ mRNA and protein expression in lung adenocarcinoma cells treated with 2-ME. Even though HIF-1 $\alpha$ protein expression decreased noticeably in these cells after treatment, it was still possible to observe it in the nuclei. These findings suggest that although 2-ME stimulates apoptosis by Bcl molecule phosphorylation and HIF expression inhibition, the decline in apoptosis could be due to the HIF molecules present in the nuclei in hypoxia; it is possible that nuclear HIFs may contribute to apoptosis inhibition through the activation of cell-stress response genes (38).

According to our data, the 2-ME therapy may not be effective during the early stages of cancer in which neoplastic cells grown in a hypoxic environment. However, due to its effect on HIF expression, 2-ME may still be effective as an antimetastatic agent and it could be used in combination with other therapeutic agents. In this regard, some 2-ME analogues have been synthesized and tested in an attempt to develop drugs with improved oral bioavailability and efficacy, for example: 2-methoxyestradiol-bis-sulphamate (2-ME-BM), 2-methoxyoestradiol-3,17-O,O-bis-sulphamate (2-MeOE2bisMATE), NanoCrystal Dispersion formula- tion of 2-ME2 (2-ME2 NCD) and sulphamoylated 2-ME analogues $(29,39-44)$. These 2-ME analogues were probed in combination with other drugs, for example: docetaxel in breast cancer (28) or paclitaxel in head and neck squamous cell carcinoma with good results (45). However, these analogues need to be tested under hypoxia, as the oxygenation levels could determine treatment response.

Finally, although HIF-1 $\alpha$ is the best-known and widely described isoform, many data suggest that HIF- $2 \alpha$ is as important as HIF-1 $\alpha$. In the present study, we found an increase in HIF- $2 \alpha$ protein expression in comparison with HIF-1 $\alpha$ when cells were cultured for $72 \mathrm{~h}$ under hypoxia. Unfortunately, it was not possible to confirm this observation by immunoperoxidase staining since this technique is not as sensitive as the western blot assay. Regarding our results, some authors report a decrease in HIF- $1 \alpha$ protein whereas HIF- $2 \alpha$ levels remained stable when A549 cells were incubated for $>6$ h under hypoxic conditions $(46,47)$. Moreover, a high HIF-2 $\alpha$ expression was observed in patients with advanced stage cancer, therefore this molecule was considered as a negative prognostic factor associated with a mutant form of Kras in non-small cell lung cancer $(48,49)$.

In summary, treatment of A549 cells with 2-ME may be ineffective to increase apoptosis under hypoxic conditions, although it could be useful to treat advanced stage cancer due to its effects on HIF expression. Understandably, further drug tests should carefully consider the conditions of normoxia and hypoxia to accurately assess whether the drug will be beneficial for the patient with a hypoxic tumor.

\section{Acknowledgements}

The present study was partially supported by grants from the Consejo Nacional de Ciencia y Tecnología (CONACYT, SALUD-2010-1-141991), and the Instituto de Ciencia y Tecnología del Distrito Federal (ICyT, PIFUTP09-281) of Mexico. The authors are grateful to Hugo Olivera, Cristina Tejas and Cuauhtémoc Sandoval for their technical support.

\section{References}

1. Lu X and Kang Y: Hypoxia and hypoxia-inducible factors: Master regulators of metastasis. Clin Cancer Res 16: 5928-5935, 2010.

2. Ye J, Wu D, Wu P, Chen $\mathrm{Z}$ and Huang J: The cancer stem cell niche: Cross talk between cancer stem cells and their microenvironment. Tumour Biol 35: 3945-3951, 2014.

3. Carmeliet P: VEGF as a key mediator of angiogenesis in cancer. Oncology 69 (Suppl 3): S4-S10, 2005.

4. Semenza GL: Hypoxia-inducible factor 1 and the molecular physiology of oxygen homeostasis. J Lab Clin Med 131: 207-214, 1998.

5. Semenza GL: HIF-1 and human disease: One highly involved factor. Genes Dev 14: 1983-1991, 2000.

6. Bertout JA, Patel SA and Simon MC: The impact of $\mathrm{O}_{2}$ availability on human cancer. Nat Rev Cancer 8: 967-975, 2008.

7. Clerici $C$ and Planès $C$ : Gene regulation in the adaptive process to hypoxia in lung epithelial cells. Am J Physiol Lung Cell Mol Physiol 296: L267-L274, 2009.

8. Fotsis T, Zhang Y, Pepper MS, Adlercreutz H, Montesano R, Nawroth PP and Schweigerer L: The endogenous oestrogen metabolite 2-methoxyoestradiol inhibits angiogenesis and suppresses tumour growth. Nature 368: 237-239, 1994.

9. Becker CM, Rohwer N, Funakoshi T, Cramer T, Bernhardt W, Birsner A, Folkman J and D'Amato RJ: 2-methoxyestradiol inhibits hypoxia-inducible factor-1 1 alpha\} and suppresses growth of lesions in a mouse model of endometriosis. Am J Pathol 172: $534-544,2008$ 
10. Escuin D, Kline ER and Giannakakou P: Both microtubulestabilizing and microtubule-destabilizing drugs inhibit hypoxia-inducible factor-1alpha accumulation and activity by disrupting microtubule function. Cancer Res 65: 9021-9028, 2005.

11. Chua YS, Chua YL and Hagen T: Structure activity analysis of 2-methoxyestradiol analogues reveals targeting of microtubules as the major mechanism of antiproliferative and proapoptotic activity. Mol Cancer Ther 9: 224-235, 2010.

12. D'Amato RJ, Lin CM, Flynn E, Folkman J and Hamel E: 2-Methoxyestradiol, an endogenous mammalian metabolite, inhibits tubulin polymerization by interacting at the colchicine site. Proc Natl Acad Sci USA 91: 3964-3968, 1994.

13. Benedikt MB, Mahlum EW, Shogren KL, Subramaniam M, Spelsberg TC, Yaszemski MJ and Maran A: 2-methoxyestradiolmediated anti-tumor effect increases osteoprotegerin expression in osteosarcoma cells. J Cell Biochem 109: 950-956, 2010.

14. Bu S, Blaukat A, Fu X, Heldin NE and Landström M: Mechanisms for 2-methoxyestradiol-induced apoptosis of prostate cancer cells. FEBS Lett 531: 141-151, 2002.

15. Rankin EB and Giaccia AJ: The role of hypoxia-inducible factors in tumorigenesis. Cell Death Differ 15: 678-685, 2008.

16. Kilic M, Kasperczyk H, Fulda S and Debatin KM: Role of hypoxia inducible factor-1 alpha in modulation of apoptosis resistance. Oncogene 26: 2027-2038, 2007

17. Sermeus A, Cosse JP, Crespin M, Mainfroid V, de Longueville F, Ninane N, Raes M, Remacle J and Michiels C: Hypoxia induces protection against etoposide-induced apoptosis: Molecular profiling of changes in gene expression and transcription factor activity. Mol Cancer 7: 27, 2008.

18. Yu EZ,Li YY,Liu XH,Kagan E and McCarron RM: Antiapoptotic action of hypoxia-inducible factor-1 alpha in human endothelial cells. Lab Invest 84: 553-561, 2004.

19. Mabjeesh NJ, Escuin D, LaVallee TM, Pribluda VS, Swartz GM Johnson MS, Willard MT, Zhong H, Simons JW and Giannakakou P: 2ME2 inhibits tumor growth and angiogenesis by disrupting microtubules and dysregulating HIF. Cancer Cell 3: 363-375, 2003

20. Brown JM and Wilson WR: Exploiting tumour hypoxia in cancer treatment. Nat Rev Cancer 4: 437-447, 2004

21. Flamant L, Notte A, Ninane N, Raes M and Michiels C: Antiapoptotic role of HIF-1 and AP-1 in paclitaxel exposed breast cancer cells under hypoxia. Mol Cancer 9: 191, 2010.

22. Sun HC, Qiu ZJ, Liu J, Sun J, Jiang T, Huang KJ, Yao M and Huang C: Expression of hypoxia-inducible factor-1 alpha and associated proteins in pancreatic ductal adenocarcinoma and their impact on prognosis. Int J Oncol 30: 1359-1367, 2007.

23. Swinson DE, Jones JL, Cox G, Richardson D, Harris AL and O'Byrne KJ: Hypoxia-inducible factor-1 alpha in non small cell lung cancer: Relation to growth factor, protease and apoptosis pathways. Int J Cancer 111: 43-50, 2004.

24. Kuo KL, Lin WC, Ho IL, Chang HC, Lee PY, Chung YT Hsieh JT, Pu YS, Shi CS and Huang KH: 2-methoxyestradiol induces mitotic arrest, apoptosis, and synergistic cytotoxicity with arsenic trioxide in human urothelial carcinoma cells. PLoS One 8: e68703, 2013.

25. Zhou NN, Zhu XF, Zhou JM, Li MZ, Zhang XS, Huang P and Jiang WQ: 2-Methoxyestradiol induces cell cycle arrest and apoptosis of nasopharyngeal carcinoma cells. Acta Pharmacol Sin 25: 1515-1520, 2004.

26. Rajkumar SV, Richardson PG, Lacy MQ, Dispenzieri A Greipp PR, Witzig TE, Schlossman R, Sidor CF, Anderson KC and Gertz MA: Novel therapy with 2-methoxyestradiol for the treatment of relapsed and plateau phase multiple myeloma. Clin Cancer Res 13: 6162-6167, 2007.

27. Sweeney C, Liu G, Yiannoutsos C, Kolesar J, Horvath D, Staab MJ, Fife K, Armstrong V, Treston A, Sidor C, et al: A phase II multicenter, randomized, double-blind, safety trial assessing the pharmacokinetics, pharmacodynamics, and efficacy of oral 2-methoxyestradiol capsules in hormone-refractory prostate cancer. Clin Cancer Res 11: 6625-6633, 2005.

28. James J, Murry DJ, Treston AM, Storniolo AM, Sledge GW, Sidor C and Miller KD: Phase I safety, pharmacokinetic and pharmacodynamic studies of 2-methoxyestradiol alone or in combination with docetaxel in patients with locally recurrent or metastatic breast cancer. Invest New Drugs 25: 41-48, 2007.

29. Matei D, Schilder J, Sutton G, Perkins S, Breen T, Quon C and Sidor C: Activity of 2 methoxyestradiol (Panzem NCD) in advanced, platinum-resistant ovarian cancer and primary peritoneal carcinomatosis: A Hoosier Oncology Group trial. Gynecol Oncol 115: 90-96, 2009.
30. Bottsford-Miller JN, Coleman RL and Sood AK: Resistance and escape from antiangiogenesis therapy: Clinical implications and future strategies. J Clin Oncol 30: 4026-4034, 2012.

31. Ma L, Li G, Zhu H, Dong X, Zhao D, Jiang X, Li J, Qiao H, $\mathrm{Ni}$ S and Sun X: 2-Methoxyestradiol synergizes with sorafenib to suppress hepatocellular carcinoma by simultaneously dysregulating hypoxia-inducible factor-1 and -2. Cancer Lett 355: 96-105, 2014.

32. Semenza GL: Evaluation of HIF-1 inhibitors as anticancer agents. Drug Discov Today 12: 853-859, 2007.

33. Harris AL: Hypoxia - a key regulatory factor in tumour growth Nat Rev Cancer 2: 38-47, 2002.

34. Teicher BA, Holden SA, al-Achi A and Herman TS: Classification of antineoplastic treatments by their differential toxicity toward putative oxygenated and hypoxic tumor subpopulations in vivo in the FSaIIC murine fibrosarcoma. Cancer Res 50: 3339-3344, 1990.

35. Mueck AO and Seeger H: 2-Methoxyestradiol - biology and mechanism of action. Steroids 75: 625-631, 2010

36. Piret JP, Mottet D, Raes M and Michiels C: Is HIF-1alpha a proor an anti-apoptotic protein? Biochem Pharmacol 64: 889-892, 2002.

37. Greijer AE and van der Wall E: The role of hypoxia inducible factor 1 (HIF-1) in hypoxia induced apoptosis. J Clin Pathol 57: 1009-1014, 2004.

38. Shen H, Yang Y, Xia S, Rao B, Zhang J and Wang J: Blockage of Nrf2 suppresses the migration and invasion of esophageal squamous cell carcinoma cells in hypoxic microenvironment. Dis Esophagus 27: 685-692, 2014.

39. Visagie MH and Joubert AM: In vitro effects of 2-methoxyestradiol-bis-sulphamate on reactive oxygen species and possible apoptosis induction in a breast adenocarcinoma cell line. Cancer Cell Int 11: 43, 2011.

40. Stander BA, Marais S, Vorster CJ and Joubert AM: In vitro effects of 2-methoxyestradiol on morphology, cell cycle progression, cell death and gene expression changes in the tumorigenic MCF-7 breast epithelial cell line. J Steroid Biochem Mol Biol 119: $149-160,2010$

41. Vorster C and Joubert A: In vitro effects of 2-methoxyestradiolbis-sulphamate on cell growth, morphology and cell cycle dynamics in the MCF-7 breast adenocarcinoma cell line. Biocell 34: 71-79, 2010.

42. Chander SK, Foster PA, Leese MP, Newman SP, Potter BV, Purohit A and Reed MJ: In vivo inhibition of angiogenesis by sulphamoylated derivatives of 2-methoxyoestradiol. Br J Cancer 96: 1368-1376, 2007.

43. Tevaarwerk AJ, Holen KD, Alberti DB, Sidor C, Arnott J, Quon C, Wilding G and Liu G: Phase I trial of 2-methoxyestradiol NanoCrystal dispersion in advanced solid malignancies. Clin Cancer Res 15: 1460-1465, 2009.

44. Visagie M, Theron A, Mqoco T, Vieira W, Prudent R, Martinez A, Lafanechère L and Joubert A: Sulphamoylated 2-methoxyestradiol analogues induce apoptosis in adenocarcinoma cell lines. PLoS One 8: e71935, 2013.

45. Ricker JL, Chen Z, Yang XP, Pribluda VS, Swartz GM and Van Waes C: 2-methoxyestradiol inhibits hypoxia-inducible factor 1alpha, tumor growth, and angiogenesis and augments paclitaxel efficacy in head and neck squamous cell carcinoma. Clin Cancer Res 10: 8665-8673, 2004

46. Sato M, Tanaka T, Maeno T, Sando Y, Suga T, Maeno Y, Sato H, Nagai $R$ and Kurabayashi M: Inducible expression of endothelial PAS domain protein-1 by hypoxia in human lung adenocarcinoma A549 cells. Role of Src family kinases-dependent pathway. Am J Respir Cell Mol Biol 26: 127-134, 2002.

47. Uchida T, Rossignol F, Matthay MA, Mounier R, Couette S, Clottes E and Clerici C: Prolonged hypoxia differentially regulates hypoxia-inducible factor (HIF)-1alpha and HIF-2alpha expression in lung epithelial cells: Implication of natural antisense HIF-1alpha. J Biol Chem 279: 14871-14878, 2004.

48. Wu XH, Qian C and Yuan K: Correlations of hypoxia-inducible factor- $1 \alpha$ /hypoxia-inducible factor- $2 \alpha$ expression with angiogenesis factors expression and prognosis in non-small cell lung cancer. Chin Med J 124: 11-18, 2011.

49. Kim WY, Perera S, Zhou B, Carretero J, Yeh JJ, Heathcote SA, Jackson AL, Nikolinakos P, Ospina B, Naumov G, et al: HIF2 $\alpha$ cooperates with RAS to promote lung tumorigenesis in mice. $\mathrm{J}$ Clin Invest 119: 2160-2170, 2009. 